\title{
Major genes and QTL influencing wool production and quality: a review
}

\author{
Ian William PURVIS*, Ian Robert FRANKLIN \\ CSIRO Livestock Industries, F.D. McMaster Laboratory, Chiswick Research Centre, \\ Armidale, NSW Australia
}

(Accepted: 5 July 2004)

\begin{abstract}
The opportunity exists to utilise our knowledge of major genes that influence the economically important traits in wool sheep. Genes with Mendelian inheritance have been identified for many important traits in wool sheep. Of particular importance are genes influencing pigmentation, wool quality and the keratin proteins, the latter of which are important for the morphology of the wool fibre. Gene mapping studies have identified some chromosomal regions associated with variation in wool quality and production traits. The challenge now is to build on this knowledge base in a cost-effective way to deliver molecular tools that facilitate enhanced genetic improvement programs for wool sheep.
\end{abstract}

gene / major gene / QTL / wool production / wool quality

\section{INTRODUCTION}

Whilst the genetic improvement of sheep bred primarily for wool production has been slow relative to other livestock species, this cannot be blamed on the tools available to the breeders and advisor geneticists. In most countries where wool sheep are grown, there is a quite sophisticated wool market and market intelligence, and the important price determinants are well quantified and communicated. This has facilitated the formal definition of breeding objectives for breeders. Of those traits that are important in an economic sense, most are either moderately or highly heritable, and are easy and inexpensive to measure to a level sufficiently precise for animal evaluation. For the few traits where measurement is difficult or expensive, such as staple strength, there are good indirect measures. For example, coefficient of variation of fibre diameter has been shown to deliver significant gains when used as a selection criterion in breeding programs focussed on apparel wool goals [12]. Most countries have high quality performance measurement programs and well-developed tools for the use of index selection utilising BLUP methodology.

\footnotetext{
* Corresponding author: ian.purvis@ csiro.au
} 
So, why is there an intense and increasing interest in the study of genes of major effect on wool production and quality traits:

(i) antagonistic correlations between two of the most important traits; clean fleece weight (CFW) and mean fibre diameter (MFD);

(ii) finding ways of dealing with one of the major deficiencies of the wool fibre in the apparel processing system; that is, when compared to many of the synthetic fibres that are used for apparel wear production, wool is of significantly lower and more variable fibre strength. This translates into a more difficult and expensive processing system;

(iii) wool currently comprises only $17 \%$ of the apparel processing system and this has been consistently decreasing over the recent decades. There is a clear need for the wool industry to deliver to the apparel wearer new and novel products. One way of achieving this goal is to produce wool with new and novel fibre properties.

Identifying genes of major effect offers the opportunity to improve production efficiency, product quality and product diversity, through utilising them in breeding programs, developing transgenic lines and by developing therapeutic agents that can be used to alter fibre attributes by altering gene expression.

The aim of this paper is to review our current knowledge of the biology underlying fibre production in wool sheep and the genes of major effect that are causative of, or associated with, variation in fibre and skin morphology phenotypes.

\section{UNDERLYING BIOLOGY OF FIBRE PRODUCTION IN WOOL SHEEP}

Examination of the underlying physiology that is integral to the production of a tissue product can be instrumental in identifying developmental steps under genetic control that are critical to the ultimate attributes of that tissue product. For example, in the production of meat there are many genes involved in the metabolic processes that control growth and differentiation of the composite cells and tissues, expression of the structural proteins that compose the tissues, and the timing or tissue specificity of gene expression and/or ligand - receptor systems that control cell function [6].

The biology of skin and wool growth in sheep has been extensively studied since the 1950's and the developmental processes at the cellular level are reasonably well understood [13]. The basic units used in the study of biology of wool growth are the wool follicle and the fibre growing from it. Although 
there is evidence for higher-level organisational mechanisms, such as the trio group of primary follicles and associated secondaries [11], it is at the level of the individual follicle that most studies have focussed.

There is clear evidence of a strong association between the developmental activities that occur during follicle initiation in the foetus and the fibre and fleece quality attributes that subsequently grow in the animal over its lifetime. The basis for the control of follicle initiation, follicle density and the consequent follicle and fibre attributes of the adult animals has been proposed to be due to (a) competition between wool follicles [11], (b) a biochemical pattern-forming mechanism (reaction-diffusion (RD) theory) [21,22], and (c) competition for a limited pool of dermal pre-papilla stem cells [20]. None of the above models adequately accounts for the observed variation. For example, the competition model does not easily accommodate the changes in follicle density that occur during foetal growth. Theories (b) and (c) each suggest that adult follicle density and MFD are co-determined at the time of follicle initiation. However, in an elegant examination of the relationship between foetal and adult follicle characteristics, Adelson et al. [1] have shown that control of follicle bulb size and fibre diameter occurs after follicle initiation. Finally, the founder cell hypothesis proposes a fixed population of pre-papilla cells, and that this population of cells acts as a limiting resource for follicle initiation [20]. Doubt has been cast over the validity of this model by the demonstration that the papilla cells divide during follicle development, and that the papilla can recruit dermal cells from the surrounding tissue [1]. Hence, the explanation remains obscure. It may be that follicles are initiated according to a RD model, but the subsequent follicle size is influenced by competition, or lateral inhibition or by some other mechanism not realised until later in life.

Whatever the explanation, it is clear that an empirical functional relationship exists between follicle density and fibre diameter, and that the relationship changes as follicle density increases [1]. Similarly, there is a well-documented relationship between length growth rate (L) and fibre diameter (D), such that $\mathrm{L} / \mathrm{D}$ (or $\mathrm{L} / \mathrm{D}^{2}$ ) for a given animal is approximately constant over a range of environmental conditions (see [16]). The negative genetic relationship between $\mathrm{L}$ and $\mathrm{D}$ is counterbalanced, at the population level, by a positive association between $\mathrm{L}$ and $\mathrm{D}$ generated by changes in total nutrient availability, and a negative association between density and L (or D). Overall, we see that there are complex interactions between each of the important components of wool growth, and the correlations that we observe in a given population reflect an admixture of relationships generated by different developmental and physiological pathways. 
The point that we wish to emphasise here is that we do not expect QTL, when identified, to each reflect the genetic relationships seen at the population level. A locus involved in follicle initiation, for example, may influence both density and diameter, but have little effect on clean wool weight. Alternatively, a locus affecting voluntary feed intake, or nutrient flow to the skin, may influence both clean wool weight and fibre diameter, but have little or no effect on follicle density. These distinctions are important in assessing the value of various QTL in genetic evaluation, especially as we attempt to produce finer wools without adversely affecting other economically important fleece value attributes.

\section{KNOWN GENES OF MAJOR EFFECT ON WOOL PRODUCTION AND QUALITY}

Prior to the widespread availability of segregation analysis using molecular markers, a number of genes (or closely linked groups of genes) having major effects on traits of the skin and fleece were identified by their extreme effect on phenotype and verified using classical crossing strategies. Recently, Sponenberg [32] has reviewed the existing knowledge on the genetics of colour in sheep skin and fibre. Similarly, Nicholas [23] has summarised the known genes affecting morphological traits and those associated with inherited disorders in the sheep. Among these are several that have profound effects on follicle morphology and fibre and fleece traits.

\subsection{Pigmentation genes}

Pigmentation patterns of fleece and hair are influenced by a number of loci, one of the most important of which is the Agouti locus. The Agouti locus codes a protein that binds to the melanocortin receptor (MC1R). In its absence, melanocyte stimulating hormone ( $\alpha \mathrm{MSH})$ binds to MC1R and signals the production of eumelanin (black to brown pigment), which causes colour expression in fleece and hair [25]. Recently, Smit et al. [31] suggested that two agouti loci exist, and our evidence supports this hypothesis. Further, it appears that a 5 bp deletion in exon 2, reported in [31], plays a role in some alleles resulting in (self colour) black sheep.

The Committee on Genetic Nomenclature of Sheep and Goats (COGNOSAG) [17] has given a comprehensive summary of alleles that result in distinct pigmentation patterns of fleece and hair. There are a number of main patterns, which are present at birth. Some do not have lateral 
symmetry, e.g. the Australian Piebald pattern $\left(\mathrm{AsP}^{\mathrm{p}}\right)$. This allele causes round spots of varying size distributed randomly over the body. It is recessive and has incomplete penetrance in homozygous carriers. Lateral symmetry in pattern distribution is caused by the badgerface $\left(\mathrm{A}^{\mathrm{b}}\right)$ or reverse badgerface $\left(\mathrm{A}^{\mathrm{t}}\right)$ alleles, which are both recessive. Sheep that are homozygous for the badgerface allele have black circles around the eyes, and ears, belly wool and legs that are black. Sheep with reversed badgerface pattern show the same pattern in white on a black body. These two alleles are dominant to the self-colour black allele $\left(\mathrm{A}^{\mathrm{a}}\right)$, which results in a completely black sheep. In addition to these there are a number of other alleles that interact with each other and cause a wide range of patterns (e.g. ticking, spotted self colour black) that are expressed either at birth and disappear later in life or comprise patterns that develop after birth. The interaction effects and the recessive character of the colour alleles make it difficult to determine the genotype through the phenotype. The agouti locus $(A S I P)$ is located on sheep chromosome 13 [31], and except for the extension locus, other loci affecting colour patterns have yet to be identified.

\subsection{Wool quality genes}

From an industry context perhaps the most important gene influencing fibre characteristics is the "N-type" gene, which has been re-named the "halo-hair 1" (HH1) gene according to the COGNOSAG nomenclature [17]. This mutation causes extreme hairiness (medullation), resulting in the production of fibre that is ideal for carpet wool production and was first found in the Romney breed [9]. This allele (now known as $\left(\mathrm{HH}^{\mathrm{N}}\right.$ ) has an incomplete dominance to the wild type. Homozygotes show approximately $65 \%$ medullation in the Romney background. By multiplying this mutation within the Romney background the Drysdale breed was developed. At the HH1 locus, two further alleles have been identified that cause similar types of medullation, and at a different locus, the "HH2", a recessive mutation (the nr) also causes similar phenotypes. By utilising these mutations, the Tukidale $\left(\mathrm{HH}^{\mathrm{T}}\right)$, Carpetmaster $\left(\mathrm{HH}^{\mathrm{J}}\right)$ and Elliotdale $(\mathrm{HH} 2)$ breeds were developed $([30,34])$. The fact that these mutations have pleiotropic effects on several traits, causing the formation of horns in females, a number of effects on follicle morphology, and a profound effect on fibre characteristics, is of interest in the context of understanding the mechanisms by which these genes function.

Another well-recognised gene effect is that which causes lustrous, light yellow wool in Merino sheep [29]. This is a dominant mutation, also reported in several other studies in Australia and New Zealand [4, 18]. 
Pleiotropic effects associated with this mutation include significantly reduced follicle density and fleece weight.

Recently Finocchiaro et al. [10] have reported segregation of the hairless ( $h r$, Mendelian recessive) in the Valle del Belice sheep breed in Sicily. A similar gene in the Poll Dorset breed was reported much earlier by Dolling and Brooker, [8] and is characterised by a complete or partial absence of fibre at birth (hypotrichosis). Three mutations of this gene have been identified within an exon of the gene, and a PCR-SSCP test developed to detect the allele responsible for the hypotrichosis phenotype. Finocchiaro et al. [10] also postulate that the $h r$ gene product may play a role in cell proliferation, differentiation and apoptosis in hair follicles as well as in the interfollicular epidermis.

\subsection{Keratin genes}

Keratin proteins are the major component of wool and are responsible for most of their structural properties. The keratins can be divided into two groups; the keratin intermediate (IF) proteins and the keratin-associated (KAP) proteins. The IF proteins form filaments that lie within a matrix of the KAP proteins. There are two families of the IF, type I and type II, and are coded for by separate gene loci that have been mapped to chromosomes 11 and 3 respectively [14]. Linkage mapping using the AgResearch IMF flock has confirmed these physical map positions [19].

The KAP proteins have been divided into three major groups on the basis of their protein sequences; (i) the high glycine-tyrosine group; (ii) the high sulphur group, and (iii) the ultra-high sulphur group. Separate multi-gene families have been shown to code for each of these groups [27]. Genetic differences at both the IF and KAP protein controlling loci may play an important role in determining phenotypes for different wool quality and production traits. Because it is now becoming possible to more cost-effectively clone and sequence wool protein genes the hypotheses suggested above can now be formally tested. The next section identifies studies that have taken the first steps in this process.

\section{PUTATIVE QTL AFFECTING WOOL PRODUCTION AND PRODUCT QUALITY}

The establishment of the animal and human resources to undertake a mapping study that has the objective of identifying genomic regions (and ultimately genes) that are associated with phenotypic differences in fibre and 
fleece traits is a major and costly undertaking. Thus, there are only a limited number of studies that have been, or are being, conducted.

Crawford [7] has characterised the features of nine flocks that have been set up to map chromosome regions. In Table I, the significant associations reported from these flocks to date are listed. It is important to note, that because of the cost of undertaking genome scans at an acceptable marker density, all studies have the common goal of optimising the range of phenotypic information collected from each animal. Thus, most studies have collected data on a range of wool and skin traits over several ages. There is a strong tendency in reports from these studies for only the primary traits of interest or traits that show significant QTL effects to be reported. Given the large number of traits recorded in these studies it is highly likely that many identified as showing significant QTL will, on further examination, turn out to be false positives [33].

There are several other studies, where suggestive QTL have been identified. However, for reasons such as low progeny numbers, inappropriate flock designs for traits under examination, or outdated analytical techniques, further or re-examination of the data is required before these studies can add substance to the search for QTL for wool or skin traits. Putative QTL have also been identified in other studies, but because of confidentiality agreements have not been publicly reported.

\section{STRATEGIES FOR USING GENES OF MAJOR EFFECT ON WOOL PRODUCTION EFFICIENCY AND PRODUCT QUALITY}

The most important challenge facing the global wool industry is to realign the production profile to respond to market signals. Over many years these signals have pointed to an increasing demand for finer wools, with the highest premiums being paid only for the finest lots that have other wool quality attributes at a premium level. In the Australian wool industry, these demand signals are being reflected in strong selection for reduced fibre diameter in some Merino flocks that were already fine. However, in others, especially those targeting the medium and strong wool fibre diameter sector, some degree of upgrading or strain replacement to reduce fibre diameter is common.

One of the difficulties, especially as wools become finer, is the negative correlation between fleece weight and fibre diameter. Although it is possible to make simultaneous genetic improvement using classical index selection if the genetic variances and covariances between the components of fleece weight with fibre diameter are known, progress can be accelerated through optimal 
Table I. Putative QTL for wool production and quality traits from linkage association studies.

\begin{tabular}{|c|c|c|c|c|c|}
\hline Trait & Analysis & Breeds & Description & Marker & Ref \\
\hline 1. Fibre diameter & $\begin{array}{l}\text { Candidate } \\
\text { gene approach }\end{array}$ & $\begin{array}{l}\text { Peppin } \\
\text { Merino }\end{array}$ & Chromosome 1 & KRTAP6 and KRTAP8 & {$[24]$} \\
\hline 2. Fibre diameter & $\begin{array}{l}\text { Genome } \\
\text { screen }\end{array}$ & $\begin{array}{l}\text { Merino } \times \\
\text { Romney }\end{array}$ & & Linked, but not named & {$[15]$} \\
\hline 3. Fibre diameter & $\begin{array}{l}\text { Segment } \\
\text { mapping } \\
\text { approach }\end{array}$ & INRA 401 & $\begin{array}{l}\text { Chromosome } 6 \\
\text { Chromosome } 25\end{array}$ & $\begin{array}{l}\text { Segment OARAE101 } \\
(20 \mathrm{cM}) \text { Segment } \\
\text { IDVGA8 to midpoint } \\
\text { with IDVGA088 }\end{array}$ & {$[26]$} \\
\hline 4. Staple strength & $\begin{array}{l}\text { Candidate } \\
\text { gene approach }\end{array}$ & Romney & Chromosome 11 & KRT1.2, B2A and B2C & {$[28]$} \\
\hline 5. Staple length & $\begin{array}{l}\text { Segment } \\
\text { mapping } \\
\text { approach }\end{array}$ & INRA 401 & $\begin{array}{l}\text { Chromosome } 3 \\
\text { Chromosome } 7 \\
\text { Chromosome } 25\end{array}$ & $\begin{array}{l}\text { Segment BMC1009- } \\
\text { OARVH34 Segment } \\
\text { ILST005 ( } 20 \mathrm{cM}) \\
\text { Segment IDGVA8 - } \\
\text { IDVGA088 }\end{array}$ & {$[26]$} \\
\hline $\begin{array}{l}\text { 6. Coefficient of variation } \\
\text { of fibre diameter }\end{array}$ & $\begin{array}{l}\text { Within sire } \\
\text { regression }\end{array}$ & INRA 401 & Chromosome 4 & McM218 & {$[2]$} \\
\hline $\begin{array}{l}\text { 7. Coefficient of variation } \\
\text { of fibre diameter }\end{array}$ & $\begin{array}{l}\text { Segment } \\
\text { mapping } \\
\text { approach }\end{array}$ & INRA 401 & $\begin{array}{l}\text { Chromosome } 7 \\
\text { Chromosome } 25\end{array}$ & $\begin{array}{l}\text { Segment ILST005 } \\
(20 \mathrm{cM}) \text { Segment } \\
\text { IDGVA8 - IDVGA088 }\end{array}$ & {$[26]$} \\
\hline $\begin{array}{l}\text { 8. Coefficient of variation } \\
\text { of fibre diameter, crimp } \\
\text { frequency, staple length }\end{array}$ & $\begin{array}{l}\text { Comparison of } \\
\text { normal } \\
\text { distributions }\end{array}$ & Finn sheep & Not stated & Not relevant & {$[5]$} \\
\hline
\end{tabular}


weighting of selection emphasis. For example, genetic variation associated with follicle initiation or with the partitioning of fibre growth within the follicle can influence the components (fibre density (N) and MFD, L and MFD, respectively), with little change in clean fleece weight. Alternatively, changes in nutrient intake and supply, which may account for a very significant proportion of the response when selecting for fleece weight, will tend to simultaneously increase both clean fleece weight and MFD. Separating these various causes requires estimates of all of the variance components, but the measurement of primary, secondary and secondary derived follicle densities is not routine and is expensive. Hence, knowledge of the effects and magnitudes of allelic differences that influence these components may provide the appropriate parameters to significantly enhance overall response in fleece value.

The other, and probably more important use of the knowledge of the genetic control of the components of fleece value is in upgrading programs, where the primary goal is to incorporate genes for reduced fibre diameter without compromising the other desirable properties, such as wool weight and body size. Three of four chromosomal regions that influence MFD have already been identified (Tab. I). Should these regions be confirmed by further studies, the techniques need to be developed that make it possible to track these regions in an upgrading program to ensure that the animals with the desirable alleles in these regions are preferentially selected.

Finally, as the Australian flock approaches a match with market demand, fibre diameter per se could become less important, and other attributes, such as staple strength, or tendency to pill, may well become the major target for breeding objectives to improve wool quality. At the ultra-fine end of the fibre diameter distribution, where there is an opportunity to develop wools with new properties, other objectives may become apparent. Here, markers that identify mutations/alleles that produce these desirable properties will become important.

The capacity to profoundly change the structural components of the wool fibre using knowledge of the genes controlling the IF/KAP protein content and balance has been demonstrated in Merino sheep [3]. The authors reported experiments that were aimed at modifying the wool fibre cortex to improve intrinsic fibre strength. Although the opposite effect was observed, these studies demonstrated that the alteration of gene expression patterns through the introduction of transgenes produced an altered fibre protein composition. With the enormous advances currently occurring in molecular technology it could reasonably be expected that the development of transgenic sheep with new and novel products will be well within our capability within the next decade. 


\section{REFERENCES}

[1] Adelson D.L., Hollis D.E., Brown G.H., Wool fibre diameter and follicle density are not specified simultaneously during wool follicle initiation, Aust. J. Agric Res. 53 (2002) 1003-1009.

[2] Allain D., Lantier I., Elsen J.M., Francois D., Brunel J.C., Weisbecker J., Schibler J., Vaiman D., Cribiu E., Gautier A., Berthon P., Lantier F., A design aiming at detecting QTL controlling wool traits and other traits in the INRA401 sheep line, in: Proc. 6th World Cong. Genet. Appl. Livest. Prod., Armidale, 11-16 January 1998, University of New England, Vol. 24, pp. 51-54.

[3] Bawden C.S., Powell B.C., Walker S.K., Rogers G.E., Expression of a wool intermediate filament keratin transgene in sheep fibre alters structure, Transgenic Res. 7 (1998) 273-287.

[4] Blair H.T., Inheritance of a major gene for excessively lustrous wool in sheep, J. Heredit. 81 (1990) 220-222.

[5] Bray A.R., O'Connell D., Saville D.J., Genes with major effects on wool traits detected in Finn cross sheep, Proc. NZ Soc. Anim. Prod. 62 (2002) 65-68.

[6] Cottle D.J., Bryson W.G., A review of markers for wool- and sheep-carcassequality traits, in: Proceedings of a Wool Industry Science and Technology Conference, Hamilton, Vic., 15-17 October 2002.

[7] Crawford A.M., A review of QTL experiments in sheep, in: Proc. Aust. Assoc. Anim. Breed. Genet. 14 (2001) 33-38.

[8] Dolling C.H.S., Brooker M.G., A viable hypotrichosis in Poll Dorset sheep, J. Heredit. 57 (1966) 86-90.

[9] Dry F., The dominant N gene in New Zealand Romney sheep, Aust. J. Agric. Res. 6 (1955) 725-769.

[10] Finocchiaro R., Portolano B., Damiani G., Caroli A., Budelli E., Bolla P., Pagnacco G., The hairless (hr) gene is involved in the congenital hypotrichosis of Valle del Belice sheep, Genet. Sel. Evol. 35 (Suppl. 1) (2003) S147-S156.

[11] Fraser A.S., Short B.F., The Biology of the fleece, in: Animal Research Laboratories Technical Paper No. 3, CSIRO Melbourne, 1960.

[12] Greeff J.C., Lewer R., Ponzoni R., Purvis I.W., Staple strength: progress towards elucidating its place in Merino breeding, in: Proc. Aust. Assoc. Anim. Breed. Genet. 11 (1995) 595-601.

[13] Hardy M.H., Lynne A.G., The pre-natal development of wool follicles in Merino sheep, Aust. J. Biol. Sci. 9 (1956) 423-441.

[14] Hediger R., Ansari H.A., Stranziger G.F., Chromosome banding and gene localizations support extensive conservation of chromosome structure between cattle and sheep, Cytogenet. Cell Genet. 57 (1991) 127-134.

[15] Henry H.M., Dodds K.G., Wuliji T., Jenkins Z.A., Beattie A.E., Montgomery G.W., A genome screen for QTL for wool traits in a Merino $\times$ Romney backcross flock, Wool Technology and Sheep Breeding 46 (1998) 213-217.

[16] Hynd P., Follicular determinants of the length and diameter of wool fibres. I. Comparison of sheep differing in $1 / \mathrm{d}$ ratio at two levels of nutrition, Aust. J. Agric Res. 45 (1994) 1137-1147. 
[17] Lauvergne J.J., Dolling C.H.S., Renieri C., Mendelian Inheritance in Sheep 1996 (MIS 96). Clamart, France, COGOVICA/COGNOSAG; Camerino, Italy, University of Camerino.

[18] McGuirke B.J., Short B.F., The "Lustre" mutation in Merino sheep, Aust. J. Exp. Agric. Anim. Husb. 7 (1967) 296-303.

[19] McLaren R., Rogers G., Davies K., Maddox J., Montgomery G., Linkage mapping of wool keratin and keratin-associated protein genes in sheep, Mamm. Genome 8 (1997) 938-940.

[20] Moore G.P.M., Jackson N., Isaacs K., Brown G., Pattern and morphogenesis in skin, J. Theoret. Biol. 191 (1998) 87-94.

[21] Nagorcka B.N., The reaction-diffusion (RD) theory of wool (hair) follicle initiation and development. 1. Primary follicles, Aust. J. Agric. Res. 46 (1995) 333-355.

[22] Nagorcka B.N., The reaction-diffusion (RD) theory of wool (hair) follicle initiation and development. 2. Original secondary follicles, Aust. J. Agric. Res. 46 (1995) 357-378.

[23] Nicholas F.W., Genetics of morphological traits and inherited disorders, in: The Genetics of Sheep, Piper L.R., Ruvinsky A. (Eds.), C.A.B. International, UK, 1997, pp. 87-132.

[24] Parsons Y.M., Piper L.R., Cooper D.W., Linkage relationships between keratinassociated protein (KRTAP) genes and growth hormone in sheep, Genomics 20 (1994) 500-502.

[25] Parsons Y.M., Fleet M.R., Cooper Des W., Isolation of the ovine agouti coding sequence, Pigment Cell Res. 12 (1999) 394-397.

[26] Ponz R., Moreno C., Allain D., Elsen J.M., Lantier F., Lantier I., Brunel J.C., Perez-Enciso M., Assessement of genetic variation explained by markers for wool traits in sheep via a segment mapping approach, Mamm. Genome 12 (2001) 569-572.

[27] Powell B.C., Rogers G.E., Analysis of hair follicle proteins, in: Keratinocyte Methods, Leigh I., Watt F. (Eds.), Cambridge University Press, UK, 1994, pp. 149-155.

[28] Rogers G.R., Hickford J.G.H., Bickerstaffe R., Polymorphism in two genes for B2 sulfur proteins of wool, Anim. Genet. 25 (1994) 407-415.

[29] Short B.F., A dominant felting lustre mutant fleece type in the Australian Merino sheep, Nature 181 (1958) 1414-1415.

[30] Sides R.H., Banks R.G., The genetics of carpet wool production: the Elliotdale breed, Proc. Aust. Assoc. Anim. Breed. Genet. 6 (1987) 356-359.

[31] Smit M.A., Shay T.L., Beever J.E., Notter D.R., Cockett N.E., Identification of an agouti-like locus in sheep, Anim. Genet. 33 (2002) 383-385.

[32] Sponenberg D.P., Genetics of colour and hair texture, in: The Genetics of Sheep, Piper L.R., Ruvinsky A. (Eds.), C.A.B. International, UK, 1997, pp. 51-86.

[33] Weller J.L., Song J.Z., Heyen D.W., Lewin H.A., Ron M., A new approach to the problem of multiple comparisons in the genetic dissection of complex traits, Genetics 150 (1998) 1699-1706.

[34] Wickham G.A., Development of breeds for carpet wool production in New Zealand, World Rev. Anim. Prod. 14 (1978) 33-40. 